\title{
Perspectives on gender parity in bioanalysis: an interview with Chad Briscoe
}

\author{
Chad Briscoe ${ }^{*, 1}$ \\ ${ }^{1}$ PRA Health Sciences, 11070 Strang Line Road, Lenexa, KS 66215, USA \\ *Author for correspondence: briscoechad@prahs.com
}

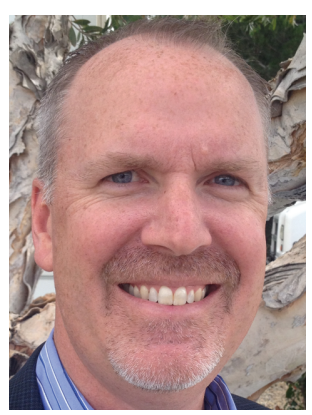

\section{Biography:}

Chad received his Bachelor of Science degree in Chemistry from Alma College in Michigan and a Master's degree in Analytical Chemistry from the University of Michigan with a focus in the use of LC-MS/MS in protein and peptide analysis. Chad's Doctorate of Philosophy at the University of Nebraska was focused on studies of protein binding via affinity LC-MS/MS and computer simulations. Chad's career of nearly 25 years includes positions of increasing responsibility ranging from bench scientist to his current role as global head of scientific affairs for Bioanalytical Science at PRA. He is a frequently invited speaker at global scientific meetings in the field of Bioanalytical Laboratory Science including WRIB, AAPS, CPSA and Land O'Lakes Bioanalysis. He is on the organizational committee and has chaired several meetings as well including the Land O'Lakes Bioanalytical Meeting and the CPSA Meeting and the upcoming AAPS meeting on cellular and gene therapy. He is also a Bioanalysis Zone leader.

Accepted for publication: 5 March 2019; Published online: 18 April 2019

\section{What advice would you give to young women hoping to embark on a career in the field?}

Bioanalysis is a great field for women. The science is exciting and dynamic and there are many opportunities to grow your career. Many of the leaders in the field are and have been women so a path is already blazed. It is most common for everyone to start their career in bioanalysis at the bench either in a CRO or a Pharma company but once you gain some experience and demonstrate initiative growing into scientific leadership positions, management roles or sales/business development roles is a common career progression for many women.

\section{How can mentors help women in their career development?}

Mentors are invaluable to career development regardless of whether you are a female or male. Because there are so many great women in the field of bioanalysis it should be easy for women to find female mentors. Bioanalysis is a supportive scientific community. We compete for business whether in drug development or in CROs but when it comes to the bioanalytical community in general, we all work together to advance the science, the regulations and career development of the next generation.

\section{What advice would you give to women hoping to pursue senior-level scientific positions?}

Do not be afraid to set your sights high. You can look across the scientific leadership in Pharma and CRO's and see many females in leadership positions. If you look at the biotech landscape it is not difficult to find female CEOs. In bioanalysis, many of the women that have achieved director and VP level roles in these organizations are very accessible and would certainly be pleased to have a young woman ask them for coaching advice. I would not be surprised if they offer to start an ongoing, supportive dialogue to a woman that shows the initiative.

\section{What are the most valuable skill sets women/diversity bring to an organization?}

We highly value diversity within our organization whether it is gender, race, national origin or any other. Bringing a unique perspective to scientific problem solving in an organization should be highly valued everywhere. Assuming you bring a level of raw talent, I think the confidence to have a voice in your organization might be the most important skill set. Bioanalysis is a growing field right now with strong competition for talent. When you are doing 
your job search, it is reasonable to look for opportunities where diverse opinions are valued, and all different types of people are seen in leadership roles.

\section{What do you see as being the most effective solution to getting more women involved in STEM careers?}

We need to continue to celebrate the accomplishments of the great women in our field. I have no doubt that when a young woman sees the accomplishments of a successful women, she has a little more confidence that she too can be successful as a scientist. I also think we should consider building balanced teams. In sports, we often hear that the championship team is not necessarily the one that has the best individual players. I think the same is true in business. You must have the best overall team if you are going to win. To me one factor to achieve this is to have the diversity of skill sets. Therefore, considering all aspects of experience that someone brings is important. Sometimes it might make sense to bring a different kind of experience and perspective to a team versus hiring the individual that worked for the most well-known professor in graduate school.

\section{Disclaimer}

The opinions expressed in this interview are those of the interviewee and do not necessarily reflect the views of Future Science Group.

\section{Financial \& competing interests disclosure}

The author has no relevant affiliations or financial involvement with any organization or entity with a financial interest in or financial conflict with the subject matter or materials discussed in the manuscript. This includes employment, consultancies, honoraria, stock ownership or options, expert testimony, grants or patents received or pending, or royalties.

No writing assistance was utilized in the production of this manuscript. 